\title{
KEEFEKTIFAN PENGGUNAAN MEDIA PICTURE STORIES DAN METODE VOCABULARY GAMES DALAM PEMBELAJARAN MEMBACA TEKS RECOUNT PESERTA DIDIK SMP N DI KECAMATAN SLEMAN
}

\author{
Rika Kurniawati dan Agus Widyantoro \\ State Islamic University Sunan Kalijaga Yogyakarta \\ Email: rheek7139@yahoo.com, agus_wiwied@yahoo.com
}

\begin{abstract}
ABSTRAK
Penelitian ini bertujuan untuk mengetahuiprestasi membaca peserta didik yang diajar menggunakan media picture stories, metode vocabulary games, dan metode tradisional dan perbedaan yang signifikan dalam prestasi membaca antara peserta didik yang diajar menggunakan media picture stories dan metode vocabulary games dengan peserta didik yang diajar menggunakan metode tradisional. Jenis penelitian ini adalah quasi experiment dengan desain pretest-posttest, nonequivalent control group design. Populasi penelitian ini adalah seluruh peserta didik kelas VIII di seluruh SMP Negeri di kecamatan Sleman. Sampel dipilih dengan menggunakan teknik cluster random sampling. Teknik analisis data menggunakan statistik non-parametrik Kruskal-WallisTest. Penelitian ini menunjukkan hasil: media picture stories, metode vocabulary games dan metode tradisional efektif digunakan dalam pembelajaran membaca teks recount dan ada perbedaan yang signifikan dalam prestasi membaca antara siswa yang diajar menggunakan media picture stories, metode vocabulary games, dan metode tradisional dalam pembelajaran membaca teks recount.
\end{abstract}

Kata Kunci: picture stories, vocabulary games, membaca teks recount

\section{THE EFFECTIVENESS OF THE USE OF PICTURE STORIES AND VOCABULARY GAMES IN THE TEACHING OF RECOUNT READING FOR STUDENTS OF JUNIOR HIGH SCHOOLS IN SLEMAN}

\begin{abstract}
This study is aimed at knowing the students' achievements in reading for students who were taught by using picture stories and vocabuary games, and by using traditional methods, and knowing the significant differences of the uses of those methods of teaching. This research is a quasi experiment with pretest-posttest designs and nonequivalent control group design. The population of this research is all grade VIII students of junior high schools in Sleman. The samples were chosen by using cluster random sampling technique. The nonparametric statistic technique of Kruskal-WallisTest was used in the data analysis. The research results show that those methods above are effective to be used in the teaching of recount reading and that there is a significant difference in the learning achievements in reading of the students who were taught by using picture stories and vocabulary games and of the students who were taught by using traditional methods.
\end{abstract}

Keywords: picture stories, vocabulary games, recount reading

\section{INTRODUCTION}

Reading is essential for life. It can open eyes and heart about something that was unknown before. So, it can increase and broaden knowledge and understanding. It also makes something far becomes near. The part of the world that is far away can be easily seen through reading. Recently the advance of the technology causes the speed of information. The latest information can be accessed and read through the Internet anytime and anywhere. Although books are no longer being the only source of 
knowledge, they should not be left since printed materials are more comfortable to be read in longer time.

Considering the importance of reading, the School-based Curriculum states that reading is one of the four language skills to be learned in English courses at schools. Specifically, in the School-based Curriculum of English for SMP/MTs, the target of the English learning is students are able to achieve the functional level that is to communicate orally and in the written word to cope daily problems. Futhermore, the scope of English courses at SMP/MTs includes the competence to understand and create various short functional texts and monologues and essays in the form of procedure, descriptive, recount, narrative and report (BSNP, 2006: 124). So, the learning of reading at SMP/MTs includes the reading of procedure, descriptive, recount, narrative and report texts.

Based on the preliminary survey on 31 July 2012 in Dinas Pendidikan Pemuda dan Olahraga in Sleman Regency, it was found that the result of the English learning in SMP/MTs in Sleman Regency was still low. The result shows that the students' average score of English of the National Final Examination in the academic year of 2011/2012 was 5.71 or the score classification was C. It shows that the students' achievement of English was still low and the English learning needs to be improved.

The low achievement of the students in English learning cannot be separated with the students' reading achievement since reading is mostly taught at schools rather than the other language skills. The low achievement of the students in English learning shows that the students' reading achievement is also still poor. It means that there are problems faced by teachers and students in the reading of procedure, descriptive, recount, narrative and report texts.

The learning of reading of the eighth grade students of SMP/MTs in the second semester includes recount and narrative texts. Previously, they have learnt descriptive and recount texts in the first semester of the eighth grade and descriptive and procedure texts in the seventh grade. This research merely examined the reading of recount texts in the second semester of the eighth grade students. The Standard of Competence is to understand meaning of short simple essay in the form of recount to interact with the surroundings. The Basic Competence is to respond meaning and logical steps in short simple essays properly, fluently and acceptably related to the surroundings in the form of recount (BSNP, 2006: 132).

Based on Board of Studies (1998: 29), a recount text is one kind of text types that intends to tell a sequence of events so that it entertains the readers. A recount text consists a story in chronological order. Common grammatical patterns of a recount consist use of past tense to locate events in relation to speaker's or writer's time.

In reading recount texts, students often find difficulties to understand the stories within the texts. The reasons are, first, the students are hard to understand the using of past tense in the texts. Although they have learnt past tense in the previous semester course, they are still confused with the changes of the verbs from present tense to past tense. Second, they are also lack of vocabulary since they less memorize it. So, they do not understand the meaning of words within the texts. Besides, they are often bored in reading recount texts since the teachers are lack of using interesting media. Usually the teachers only use textbooks without pictures and colours. In addition, the teachers usually use traditional methods to teach reading recount texts. They ask the students to read the text and find the meaning of difficult words from a dictionary. Then, they ask the students to answer questions based on the text. This method makes the students bored and uninterested with the lessons. These problems cause their reading achievement to become low.

One of factors that causes the students' low reading achievement includes the lack of using instructional media in the learning of reading recount texts. In fact, instructional media have important roles in the learning. According to Newby, et.al (2000: 91), media are the tools used to create learning experiences. They are to facilitate communication and enhance learning. They do this by providing a stimulus-rich environment. They can also provide vicarious experiences. Students do not 
have to go to a certain place to see it. Visual media give added meaning to words. Students can see how an event happened, not just read a description of it. The purposes of the using of media in reading recount textsare to increase student interest and motivation to learn and to make students easier to learn.

One of instructional media that can be used for reading recount texts is a picture story. It is a visual medium that consists of a recount text with a series of pictures that represents a story in chronological order. The text included in this medium contains a story. People, especially students, love stories. They love to hear, read and tell stories. Students can find stories in recount texts. However, stories can be boring for students if they are merely in texts without pictures and colours. Picture stories are texts that contain a series of colourful pictures. Picture stories are easy to find. They can be found in magazines, newspapers, books, the Internet and other sources. Teachers can use them as instructional media in the classrooms. However, the phenomena show that they are less used by teachers in reading recount texts, although they are many and can easily be found.

Besides instructional media, instructional methods also play important roles in learning. Newby,et.al. (2000: 91) have described instructional methods as "presentation formats." They are procedures selected to help students achieve lesson objectives. Instructional games are a type of methods that provides an appealing environment in which students follow prescribed rules as they strive to achieve a challenging goal.

One of instructional games that can be applied at classrooms is vocabulary games. According to Thornbury (2002: 102), “... it would be wrong to suggest that vocabulary learning has to be all work and no play. Language play, including word games, has a long history. Children of all cultures seem to enjoy games..." Students also love to play games. They can learn vocabulary in recount texts through games. There are many vocabulary games that can be applied at classrooms such as Spelling Bee, Scrabble, Word Snap, Word Race and others. These games can be found in books, toy stores, the Internet and others.
Teachers can use them as instructional games in the classrooms. The general phenomena at schools show that teachers rarely involve their students in vocabulary games in teaching English, especially in teaching reading recount texts, although vocabulary games are many and can easily be found.

Students are rarely taught with interesting learning media and fun activities in the class such as picture stories and vocabulary games. To apply picture stories as instructional media and vocabulary games as instructional methods for reading recount texts in classrooms, first, it is needed to know their effectiveness through research. However, it had not been examined through research. Therefore, this research was important to conduct.

Based on the background of the problem above, some problems can be identified as follows: (1) the SMP students' achievement of English in Sleman Regency was still low; (2) the students' low achievement in English learning shows that the students' reading achievement is also still poor; (3) there are problems faced by teachers and students in the reading of procedure, descriptive, recount, narrative and report texts; (4) students often find difficulties to understand the stories within the recount texts; (5) students are hard to understand the using of past tense in the recount texts; (6) students are also lack of vocabulary since they less memorize it; (7) teachers are lack of using instructional media in teaching reading recount texts; (8) teachers usually use traditional methods to teach reading recount texts; (9) there are many picture stories and vocabulary games that can be found but they are less used by teachers in reading recount texts; (10) the effectiveness of picture stories as instructional media and vocabulary games as instructional methods for reading recount texts in classrooms had not been examined through research.

Based on the discussion above, there are some problems that can be identified. To conduct focused and deeper research, delimitation of the problems is needed. There are some types of texts to be learned in SMP including recount texts. The researcher conducted research on the recount texts since it had not been examined through research. This research examined 
picture stories as instructional media and vocabulary games as instructional methods for reading recount texts because their effectiveness had not been found. This research examined the students of the eighth grade of the second semester in SMP N 4 Sleman and SMP N 5 Sleman because reading recount texts was taught at this level. This research was conducted in SMPN 4 Sleman and SMPN 5 Sleman since these schools had similar conditions. It was seen on their students' score of the National Final Examination of the academic year of 2011/2012 that their students had the similar score. In these schools, the effectiveness of picture stories and vocabulary games for reading recount texts had not been examined through research. Based on those considerations, the researcher then finally preferred to focus on investigating the effectiveness of picture stories and vocabulary games for reading recount texts of the students of the eighth grade of the second semester in SMP N 4 Sleman and SMP N 5 Sleman.

Based on the limitation of the problem above, the formulation of the problem in this research: (1) What was the reading achievement of the students who were taught using picture stories like? (2) What was the reading achievement of the students who were taught using vocabulary games like? (3) What was the reading achievement of the students who were not taught using picture stories and vocabulary games like? (4) Was there any significant difference of the reading achievement between the students who were taught using picture stories and vocabulary games and those who were not taught using picture stories and vocabulary games?

Based on the formulation of the problem above, this research was to describe as follows: (1) The reading achievement of the students who were taught using picture stories; (2) The reading achievement of the students who were taught using vocabulary games; (3) The reading achievement of the students who were not taught using picture stories and vocabulary games; (4)The significant difference of the reading achievement between the students who were taught using picture stories and vocabulary games and those who were not taught using picture stories and vocabulary games.
The research findings were expected to have theoretical and pragmatic significances. Theoretically, the researcher hoped that this research could enrich the knowledge and gave the scientific proof about the effectiveness of picture stories and vocabulary games in the learning of reading recount texts. Practically, this research could be used by: (1) Teachers, as information to show the importance of supporting their students to read, of providing suitable and interesting learning media and games in classes, and of creating enjoyable the reading atmosphere at classrooms; (2) Other researchers, as a reference that might inspire and encourage them to conduct other similar studies.

\section{METHOD}

This research is quasi-experimental. It was based on Campbell \& Stanley in Seliger \& Shohamy, 1989: 148) who say that quasiexperimental designs are constructed from situations which already exist in the real world, and are probably more representative of the condition found in educational contexts. This research is conducted under conditions in which it is difficult to control many of the variables and in which subjects cannot be assigned to special groups for the purposes of the research.

This quasi-experimental research used the pretest-posttest, nonequivalent control group design. It was adapted from Wiersma \& Jurs (2009: 169). The paradigm is shown in the following table.

Table 1. The Pretest-Posttest, Nonequivalent Control Group Design

\begin{tabular}{cccc}
\hline Group & Pretest & Treatment & Posttest \\
\hline Experiment 1 & $\mathrm{O}_{1}$ & $\mathrm{X}_{1}$ & $\mathrm{O}_{2}$ \\
\hline Experiment 2 & $\mathrm{O}_{3}$ & $\mathrm{X}_{2}$ & $\mathrm{O}_{4}$ \\
\hline Control & $\mathrm{O}_{5}$ & - & $\mathrm{O}_{6}$ \\
\hline
\end{tabular}

Notes:

$\mathrm{O}_{1}=$ the pretest of the experimental group 1 (EG1)

$\mathrm{O}_{2}=$ the posttest of the experimental group 1 (EG1)

$\mathrm{O}_{3}=$ the pretest of the experimental group 2 (EG2)

$\mathrm{O}_{4}=$ the posttest of the experimental group 2 (EG2)

$\mathrm{O}_{5}=$ the pretest of the control group (CG)

$\mathrm{O}_{6}=$ the posttest of the control group $(\mathrm{CG})$

$\mathrm{X}_{1}=$ the treatments using picture stories

$\mathrm{X}_{2}=$ the treatments using vocabulary games 
The pretest-posttest, nonequivalent control group design ministers to check the extent of group similarity, and the pretest scores may be used for statistical control or for generating gain scores (Wiersma \& Jurs, 2009: 169).

The steps of research procedure in the schools are stated below: (1) Preparation. In this step, a syllabus, lesson plans, learning materials, media, pretest and posttest instruments were prepared. Meetings with the English teachers to plan and organize the instructions during the research were also done in this step; (2) Pretest. The pretest was administered to the three groups. The result was used as preliminary data; (3) Treatment. An instruction by using picture stories and vocabulary games was implemented to the experiment groups. An instruction by using the traditional method was implemented to the control group. Both courses were completed in 9 meetings. One meeting lasted for 90 minutes; (4) Posttest. The posttest was also administered to the three groups after the 9 meetings of treatment. The result was used as the data of the research; (5) Data analysis of the pretest and posttest; (6) Report writing.

This research was carried out at SMP N 4 Sleman and SMP N 5 Sleman. The researcher had done a pre-survey for two months in JanuaryFebruary 2013 while the research had been done in $29^{\text {th }}$ April- $8^{\text {th }}$ June 2013. The research in the experimental group 1 was conducted in $29^{\text {th }}$ April- $3^{\text {rd }}$ June 2013. The research in the experimental group 2 was conducted in $3^{\text {rd }}$ May- $3^{\text {rd }}$ June 2013. The research in the control group was conducted in $1^{\text {st }}$ May- $8^{\text {th }}$ June 2013. The research was conducted in 11 meetings for each group. The research activities consisted of a pretest, 9 meetings of treatments and a posttest. It was in the second semester of the academic year of 2012-2013. This research was conducted in SMP N 4 Sleman and SMP N 5 Sleman since these schools have similar condition. It was seen on their students' score of the National Final Examination of the academic year of 2011/2012 that their students have the similar score.

The population of this research is the eight grade students of SMP N in Sleman Subdistrict. There are 5 SMP Ns in Sleman Subdistrict.The samples of the research are two classes of the eighth grade students of SMP N 4 Sleman (the students of class $8 \mathrm{~B}$ and $8 \mathrm{C}$ ) and one class of the eighth grade students of SMP N 5 Sleman (the students of class 8C). Three of the classes were determined by cluster random sampling technique. One class is the control group and the others are the experimental groups. Based on the cluster random sampling, class 8B of SMP N 4 Sleman was chosen as the experimental group 1 that would be given treatments using picture stories. The number of its students was 36. Class $8 \mathrm{C}$ of SMP N 4 Sleman was the experimental group 2 with treatments using vocabulary games. It had 35 students. Class 8C of SMP N 5 Sleman was the control group that would use traditional methods with the number of students of 33 . So, the number of the samples are then 104 students in total.

The research variables in this study are written as follows: (1) independent variables: picture stories, vocabulary games and traditional method; (2) dependent variable: the students' reading achievement of recount texts.

The technique of the data collecting was using a pretest and posttest. The preliminary data of the research was taken from the result of the pretest. The same test was given to the experiment and control groups. The test was used to measure students' reading achievement of recount texts before the treatments were given. The posttest was given after the treatments were completed, that was after 9 meetings. It was used to measure students' reading achievement of recount texts after the treatments were given.

The pretest of the experimental group 1 (picture stories group) was done on 29 April 2013, of the experimental group 2 (vocabulary games group) was done on 3 May 2013, and of the control group (traditional method group) was done on 1 May 2013. While the posttest of the experimental group 1 was done on 3 June 2013, of the experimental group 2 was done on 3 June 2013, and of the control group was done on 8 June 2013.

The instrument of data collecting was a reading test in the form of multiple choice items. It was used to measure students' reading achievement of recount texts before and after the treatments. The same instrument was used in both the experiment and control groups. The 
pretest and posttest used the same instrument but the order of the numbers was random.

In order to gain the validity of the instrument there were four steps to follow: (1) Setting the specification based on the Standard of Competence, Basic Competency, and Indicators; (2) Compiling test items based on the specification; (3) Getting the instrument validation by an expert and some colleagues; and (4) Revising the instrument based on the expert and colleagues' notes.

Before being conducted in the pretest and posttest, the instrument was tried out first to test the validity and the reliability. The try out instrument was a reading test that followed the specification of the test. The specification was based on the Standard of Competence and the Basic Competency of English subject for SMP/ MTs in the School-based Curriculum (BSNP, 2006: 132). The indicators were taken from the teachers' syllabus that was used in SMP N 4 Sleman and SMP N 5 Sleman.

After setting the specification of the test, then the researcher compiled the test items based on the specification. Next, the researcher asked an expert and some colleagues to check the construct and content validity of the try out instrument. After getting the instrument validation from the expert and the colleagues, the researcher revised the instrument based on their notes.

Before the instrument was used to collect the data, the researcher tried out it first. The instrument try out was carried out on $28^{\text {th }}$ March 2013 in class 8D of SMP N 2 Sleman. There were 35 students who followed the try out. The try out was conducted in SMP N 2 Sleman because the students had similar condition with both in SMP N 4 Sleman and SMP N 5 Sleman. It was seen on their students' score of the National Final Examination of the academic year of 2011/2012 that their students had the similar score.After the try out, the validity and reliability tests were done. They were conducted in order to assure that the instrument of the research is valid and reliable before they are administered in the actual research.

According to Creswell (2008: 169) validity means "the individual's scores from an instrument make sense, are meaningful, and enable you, as the researcher, to draw good conclusions from the sample you are studying to the population." After the try out, the item validity of the instrument was tested by Item and Test Analysis Program (ITEMAN) version 3.00. The ITEMAN was used since it analyzes test and survey item response data and provides conventional item analysis statistics (proportion/percentage endorsing and item-total correlations) for each item, in order to assist in determining the extent to which items are contributing to the reliability of a test and which response alternatives are functioning well for each item. In addition to item-level statistics the ITEMAN program also provides statistical indicators on the performance of the test as a whole (mean, standard deviation, reliability, median p-value).

Based on the item validity test using ITEMAN, for the indicator of identifying various meanings of the recount text, it was found that the valid item numbers that could be used in the research instrument were the item number $1,3,4,5,6,7,8,9,10,11,12,13,15$, $17,20,21,22,23,25,26,28,32,33,35,36,37$, $39,42,43,45,46,47,48,49$ and 50. They were 35 item numbers. Those that were dropped were the item number 14, 18, 19, 24, 27, 29, 30, 31 and 40 . They were 9 item numbers.

For the indicator of identifying the communicative objectives of the recount texts, it was found that the valid item numbers that could be used in the research instrument were the item number $2,16,38,41$, and 44 . They were 5 item numbers. Those that were dropped were the item number 34. It was 1 item number.

The total of valid item numbers were 40. They were used in the research instrument for conducting the pretest and posttest. The total of invalid item numbers were 10 . They were not used in the research instrument for conducting the pretest and posttest.

In accordance with Creswell (2008, p.169), reliability means "scores from an instrument are stable and consistent." To examine the reliability of the instrument, the researcher also used ITEMAN program.

According to Zulaiha (2008: 3), the alpha reliability coefficient can range in value from 0.0 to 1.0 . The test is more reliable if 
it is closer to value 1.0. The instrument was considered reliable if the reliability coefficient was higher than 0.70 as stated by George and Mallery (2003) in Gliem \& Gliem (2003: 87) who provide the following rules of thumb for the reliability coefficient: “_>.9-Excellent,_>.8Good,_>.7-Acceptable,_>.6-Questionable, _> .5- Poor, and _<.5-Unacceptable." The alpha reliability coefficient of this test was 0.757 . It means that this test was quite reliable to collect the data in this research because the alpha coefficient was higher than 0.70 .

To analyze the data obtained, the researcher used descriptive statistics and inferential statistics techniques. The inferential analysis consisted of: (1) test of normality using One-Sample Kolmogorov-Smirnov Test; (2) test of homogeneity using Levene's Test; and (3) test of hypothesis using Kruskal-Wallis Test. The computations were done by computer program SPSS 16.00 and the researcher merely interpreted the findings.

The descriptive analysis was used to provide answers to the questions about the students' reading achievement. The descriptive analysis included the mean, standard deviation, minimum, and maximum of the students' scores. The mean is the average score obtained by the subjects of the study. Meanwhile, the standard deviation is the average variability of all the scores around the mean.

In categorizing the scores of the students' reading achievement, the researcher utilized the classification proposed by Nurgiyantoro (2001, p.401). He suggested that the amount of the ideal mean $\left(\overline{\mathrm{X}}_{\mathrm{i}}\right)$ is $60 \%$ of the students' maximum score and the amount of the ideal standard deviation $\left(S_{i}\right)$ is $1 / 4$ of $\bar{X}_{i}$ Based on the data in this research the students' maximum score is 8.25. Then we can find that $\mathrm{Xi}=60 \% \times 8.25=$ 4.95 and $\mathrm{S}_{\mathrm{i}}=1 / 4 \mathrm{X} 4.95=1.2375$.

Before conducting the hypothesis test, the data condition was examined by using normality and homogeneity test to determine the appropriate statistics analysis that agreed with the data condition.

The normality test was done before the hypothesis test. This test was carried out to know whether there is a normal distribution of data or not. The normality test used One-Sample
Kolmogorov-Smirnov Test of SPSS 16.00 in the level of significance at 0.05 . If the test result is normal, the statistic accounting result can be generalized at the research population. The normality test was done to the pretest and posttest data in experimental and control groups. To examine the normality of data, the researcher can see the score of $p$. If $p>0.05$, it means that the data distribute normally. The result of the normality test shows that $p>0.05$ so that all data in this research distribute normally.

The homogeneity test was carried out to know the variance score similarity of the population. This test used Levene's Test of SPSS 16.00. In this case, the researcher examined the variances homogeneity based on as follows: (1) if the probability (Sig.) score is $<0.05$. It meant that the variances are not homogeneous, and (2) if the probability (Sig.) score is $>0.05$ meaning that the variances are homogeneous.

The hypothesis proposed to examine the homogeinity of variance is as follows: $\mathrm{H}_{0}$ : Variance of variable is homogeneous $\mathrm{Ha}$ : Variance of variable is heterogeneous $\mathrm{H}_{0}$ will be accepted if Sig. $>0.05$.

Based on the Levene's Test that has been done, it was found that the probability (Sig.) score is $<0.05$. It meant that the variances are not homogeneous.

The homogeneity test using the Levene's Test shows that the variances are not homogeneous. Consequently, the analysis of the data could not use ANACOVA. Therefore, the hypothesis test merely could be done by using non-parametric statistics that was KruskalWallis Test. The computations were done by computer program of SPSS 16.00. This test is used to examine 3 samples of data or more that are independent. This procedure is used to test hypothesis of $\mathrm{k}$ sample independent for ordinal data. If the data is in the form of interval or ratio, then it needs to be changed into the ordinal form (Wahana, 2009: 154). This testwas done to the pretest and posttest data in experimental and control groups.

The hypothesis proposed in this test is as follows:

$\mathrm{H}_{0}: \mu_{1}=\mu_{2}=\mu_{3}=\ldots=\mu_{\mathrm{k}}$

$\mathrm{H}_{1}$ : at least there is one different treatment 
While the norm of decision making is as follows. $\mathrm{H}_{0}$ will be accepted if Sig. $>0.05$. $\mathrm{H}_{0}$ will be rejected if Sig. $<0.05$. The result of the hypothesis test in this research was Sig. < 0.05 . It means that $\mathrm{H}_{0}$ was rejected. Otherwise, $\mathrm{H}_{1}$ was accepted.

\section{RESULTS AND DISCUSSION}

The Reading Achievement of the Students who are Taught by Using Picture Stories

The differences of the pretest and posttest result of the picture stories group are seen from the descriptive statistics that is shown in the following table.

Table 2. The Descriptive Statistics of the Pretest and Posttest Result of the Picture Stories Group

\begin{tabular}{cccccc}
\hline $\begin{array}{c}\text { Picture } \\
\begin{array}{c}\text { Stories } \\
\text { Group }\end{array}\end{array}$ & N & Mean & $\begin{array}{c}\text { Standard } \\
\text { Deviation }\end{array}$ & $\begin{array}{c}\text { Min. } \\
\text { Score }\end{array}$ & $\begin{array}{c}\text { Max. } \\
\text { Score }\end{array}$ \\
\hline Pretest & 36 & 4.7847 & .57057 & 3.25 & 6.50 \\
\hline Posttest & 36 & 5.3542 & .67182 & 4.25 & 8.00 \\
\hline
\end{tabular}

From the tableabove, it can be seen clearly that there were differences in the pretest and posttest resultof the picture stories group. The mean increase of the picture stories group was about 0.6 points from 4.7 (pretest) to 5.3 (posttest). The standard deviation increased for about 0.1 point from 0.57 (pretest) to 0.67 (posttest). The minimum and the maximum scores also showed some changes. The minimum score of picture storiesgroup in the pretest was 3.25. It changed to be 4.25 in the posttest.The maximum was 6.5 (the pretest) compared with 8.00 (the posttest).

According to the data, it can be concluded that the result of the posttest was better than that of the pretest. It shows that the treatments given to the picture stories group made the students get the better reading achievement than before.

\section{The Reading Achievement of the Students who are Taught by Using Vocabulary} Games

The differences of the pretest and posttest result of the vocabulary games group are seen from the descriptive statistics that is shown in the following table.
Table 3. The Descriptive Statistics of the Pretest and Posttest Result of the Vocabulary Games Group

\begin{tabular}{cccccc}
\hline $\begin{array}{c}\text { Vocabulary } \\
\text { Games } \\
\text { Group }\end{array}$ & N & Mean & $\begin{array}{c}\text { Standard } \\
\text { Deviation }\end{array}$ & $\begin{array}{c}\text { Min. } \\
\text { Score }\end{array}$ & $\begin{array}{c}\text { Max. } \\
\text { Score }\end{array}$ \\
\hline Pretest & 35 & 6.3071 & 1.02914 & 4.00 & 7.75 \\
\hline Posttest & 35 & 6.5000 & 1.24558 & 4.00 & 8.25 \\
\hline
\end{tabular}

From the tableabove, it can be seen clearly that there were differences in the pretest and posttest resultof the vocabulary games group. The mean increase of the vocabulary gamesgroup was about 0.2 points from 6.3 (pretest) to 6.5 (posttest). The standard deviation increased for about 0.2 point from 1.02 (pretest) to 1.24 (posttest). The minimum scoresof vocabulary games group in the pretest and posttest were the same i.e. 4.00.The maximum was 7.75 (the pretest) compared with 8.25 (the posttest).

According to the data, it can be concluded that the result of the posttest was better than that of the pretest. It shows that the treatments given to the vocabulary games group made the students get the better reading achievement than before.

\section{The Reading Achievement of the Students who are Taught by Using the Traditional Method}

The differences of the pretest and posttest result of the traditional methodgroup are seen from the descriptive statistics that is shown in the following table.

Table 4. The Descriptive Statistics of the Pretest and Posttest Result of the Traditional Method Group

\begin{tabular}{cccccc}
\hline $\begin{array}{c}\text { Traditional } \\
\text { Method } \\
\text { Group }\end{array}$ & N & Mean & $\begin{array}{c}\text { Standard } \\
\text { Deviation }\end{array}$ & $\begin{array}{c}\text { Min. } \\
\text { Score }\end{array}$ & $\begin{array}{c}\text { Max. } \\
\text { Score }\end{array}$ \\
\hline Pretest & 33 & 4.9318 & 1.35968 & 2.50 & 8.00 \\
\hline Posttest & 33 & 6.3561 & 1.00978 & 3.75 & 8.25 \\
\hline
\end{tabular}

From the table above, it can be seen clearly that there are differences in the pretest and posttest result of the traditional method group. The mean increase of the traditional method group was about 1.4 points from 4.9 
(pretest) to 6.3 (posttest). The standard deviation decreased for about 0.3 point from 1.3 (pretest) to 1.00 (posttest). The minimum and the maximum scores also showed some changes. The minimum score of traditional method group in the pretest was 2.50 . It was changed to be 3.75 in the posttest. The maximum was 8.00 (the pretest) compared with 8.25 (the posttest).

According to the data, it can be concluded that the result of the posttest was better than that of the pretest. It shows that the learning materials given to the control group by using the traditional method also made the students get the better reading achievement than before.

To know whether the distribution of the datawas normal or not, the writer applied One-Sample Kolmogorov-Smirnov Testof SPSS 16.00 in the level of significance at 0.05 . The normality test was done to the pretest and posttest data in experimental and control groups. To examine the normality of the data, the researcher was based on the score of $p$. If $p$ $>0.05$, it meant that the data were distributed normally.

The score of $p$ in the pretest of the picture stories group was 0.490 , that of the vocabulary games group was 0.577 and that of the traditional method group was 0.171 . All of the results showed that all of the $p$ scores $>$ 0.05 . It means that the distribution of the data wasnormal. It can be concluded that the result of the normality test showed that $p>0.05$. So, all data in this research were distributed normally.

For the homogeneity test, Levene's Test was used. This test was carried out to know the homogeneity of the population. The analysis was done by SPSS 16. In this case, the researcher examined the variance homogeneity based on as follows: (1) if the probability (Sig.) score is< 0.05 , the variances are not homogeneous, and (2) if the probability (Sig.) score is $>0.05$, the variances are homogeneous.

Based on the Levene's Test that has been done, it was found that $\mathrm{F}$ was 5.996 with the significance of probability (Sig.) 0.003 . It waslower than $0.05(0.003<0.05)$. It meant that was rejected. It can be concluded that the variances were not homogeneous.
Based on the result of the homogeneity test, the variances were not homogeneous. So, the requirement to conduct the parametric test for the hypothesis test was not fulfilled. Therefore, the hypothesis test was done by using the nonparametric test, i.e. KruskalWallis test. This test was aimed at answering one of the questions of the formulation of the problem of the research: is there any significant difference of the reading achievement between the students who are taught using picture stories and vocabulary games and those who are taught using traditional method?

The null hypothesis in this research is that there is no difference in the reading achievement between the students who are taught using picture stories and vocabulary games and those who are taught using a traditional method. The alternative hypothesis is thatthere is a significant difference in the reading achievement between the students who are taught using picture stories and vocabulary games and those who are taught using a traditional method.If the probability $>0.05$, is accepted and is rejected. If the probability < 0.05 , is rejected and s accepted.

Based on the Kruskal-Wallis test, the $\mathrm{F}$ of pretest score was 31.777and that of posttest score was 24.075 with the significance of probability 0.000 . It was lower than 0.05 $(0.000<0.050)$. It meant that was rejected and was accepted. It can be concluded that there is a significant difference in the reading achievement between the students who are taught using picture stories and vocabulary games and those who are taught using a traditional method.

\section{DISCUSSION}

Based on the result of the data analysis, the research result was interpreted. There were some tests that had beendone. The validity and reliability test were done by using the ITEMAN program after the try out of the research instrument. It was to know the item validity and reliability of the research instrument and whether the research instrument was already able to be used to take the data. The result of the tests showed that the instrument was valid and reliable. It meant that the researcher can use the instrument as well. 
After taking the data, the researcher did descriptive statistics. It was used to know about the mean, standard deviation and minimum and maximum score of the data in each group of research. Based on the descriptive computation, the result showed that there were differences in each group of the pretest and posttest scores. The mean of the pretest of the picture stories group rose about 0.6 points from 4.7 (pretest) to 5.3 (posttest). Further, the mean of the pretest of the vocabulary games group increased about 0.2 points from 6.3 (pretest) to 6.5 (posttest). The mean of the pretest of the traditional method group or the control group improved 1.4 points from 4.9 (pretest) to 6.3 (posttest).

After finding the descriptive statistics, then, the researcher did the inferential statistics. The data that the researcher got must be tested about its normality and homogeneity. It was a kind of pre-analysis testing by using SPSS 16. The normality was tested using One-Way Kolmogorov Smirnov. The result of the test showed that the distribution of the data of the research was normal. Then, it continued to the homogeneity test using Levene's Test. It was tested to know whether the variances were homogeneous or not. The result of the test showed that it wasnot homogeneous. It was because the computation in the Levene's Test showed that $\mathrm{F}$ was 5.996 with the significance of 0.003 . It was lower than $0.05(0.003<0.05)$. It meant that was rejected.

Next was the hypothesis test. Based on the result of the homogeneity test stating that the variances were not homogeneous, the hypothesis test was done by nonparametric test using Kruskal-Wallis test. The computation result using Kruskall-Wallis Test with SPSS 16 showed thatthe $\mathrm{F}$ of pretest score was 31.777 and that of posttest score was 24.075 with the significance of probability 0.000 . It was lower than $0.050(0.000<0.050)$. It meant that was rejected and was accepted. It can be concluded that there is a significant difference in the reading achievement between the students who are taught using picture stories and vocabulary games and those who are taught using a traditional method.

In this part, the researcher will discuss the results of the research. They areas follows:
(1) the reading achievement of the students who are taught using picture stories; (2) the reading achievement of the students who are taught using vocabulary games; (3) the reading achievement of the students who are taught using the traditional method; (4) the significant difference of the reading achievement between the students who are taught using picture stories and vocabulary games and those who are taught using the traditional method.

\section{The Reading Achievement of the Students who are Taught Using Picture Stories}

Based on the data analysis, it wasfound that picture stories as the learning media were effective to be applied in the reading of recount texts of the $8^{\text {th }}$ grade students of SMP N 4 Sleman. It was shown from the reading pretest and posttest scores. The mean of the picture stories group improved about 0.6 points from 4.7 (pretest) to 5.3 (posttest). The minimum score changed from 3.25 (pretest) to 4.25 (posttest). The maximum score changed from 6.5 (pretest) to 8.00 (posttest). In other words, the use of picture stories as the media in the learning can improve the score of students' reading achievement.

\section{The Reading Achievement of the Students who are Taught Using Vocabulary Games}

Based on the data analysis, it was found that vocabulary gamesas the learning method were effective to be applied in the reading of recount texts of the $8^{\text {th }}$ grade students of SMP N 4 Sleman. It was shown fromthe reading pretest and posttest score. The mean of the vocabulary games group increased about 0.2 points from 6.3 (pretest) to 6.5 (posttest). The minimum score of the pretest and posttest did not changed (4.00). However, the maximum score changed from 7.75 (pretest) to 8.25 (posttest). In other words, the use of vocabulary games in the learning can improve the score of students' reading achievement.

\section{The Reading Achievement of the Students who are Taught Using the Traditional Method} Based on the data analysis, it was found that the traditional method was effective to be applied in the reading of recount texts of the $8^{\text {th }}$ 
grade students of SMP N 5 Sleman. It was shown from the reading pretest and posttest scores. The mean of the traditional method group improved about 1.4 points from 4.9 (pretest) to 6.3 (posttest). The minimum score changed from 2.5 (pretest) to 3.75 (posttest). The maximum score changed from 8.00 (pretest) to 8.25 (posttest). In other words, the use of traditional method in the learning can also improve the score of students' reading achievement.

The Significant Difference of the Reading Achievement between the Students who are Taught Using Picture Stories and Vocabulary Games and Those who are Taught Using the Traditional Method

Based on the hypothesis test by using Kruskal-Wallis test with SPSS 16, the F of the pretest score was 31.777 and that of the posttest score was 24.075 with the significance of 0.000 . It was lower than $0.050(0.000<0.050)$. It meant that was rejected and was accepted. It can be concluded that there is a significant difference in the reading achievement between the students who are taught using picture stories and vocabulary games and those who are taught using a traditional method.

\section{CONCLUSION}

Based on the data analysis and the discussion in the previous chapter, it can be concluded as follows: (1) it was found that picture stories as the learning media was effective to be applied in reading recount texts of the $8^{\text {th }}$ grade students of SMP N 4 Sleman. It was shown from the reading pretest and posttest scores. The mean of the picture stories group improved about 0.6 points from 4.7 (pretest) to 5.3 (posttest). The minimum score changed from 3.25 (pretest) to 4.25 (posttest). The maximum score changed from 6.5 (pretest) to 8.00 (posttest). In other words, the use of picture stories as the media in the learning of reading recount texts can improve students' reading achievement; (2) it was found that vocabulary games was effective to be applied in reading recount texts of the $8^{\text {th }}$ grade students of SMP N 4 Sleman. It was shown from the reading pretest and posttest scores. The mean of the vocabulary games group increased about 0.2 points from 6.3 (pretest) to 6.5 (posttest). The minimum score of the pretest and the posttest did not changed (4.00). However, the maximum score changed from 7.75 (pretest) to 8.25 (posttest). In other words, the use of vocabulary games in the learning of reading recount texts can improve students' reading achievement; (3) it was found that the traditional method (the learning without using picture stories and vocabulary games) was effective to be applied in reading recount texts of the $8^{\text {th }}$ grade students of SMP N 5 Sleman. It was shown from the reading pretest and posttest scores. The mean of the traditional method group improved about 1.4 points from 4.9 (pretest) to 6.3 (posttest). The minimum score changed from 2.5 (pretest) to 3.75 (posttest). The maximum score changed from 8.00 (pretest) to 8.25 (posttest). In other words, the use of a traditional method in the learning of reading recount texts can also improve students' reading achievement (4) there is a significant difference in the reading achievement between the students who are taught using picture stories and vocabulary games and those who are taught without using picture stories and vocabulary games (using a traditional method). It was based on the hypothesis test by using Kruskal-Wallis test with SPSS 16 that shows that the F of pretest scores was 31.777 and that of posttest scores was 24.075 with the significance of 0.000 . It was lower than $0.050(0.000<0.050)$. It meant that was rejected and was accepted.

\section{Ucapan Terima Kasih}

Artikel ini disusun berdasarkan tesis yang telah diujikan dan direvisi. Oleh karena itu, saya mengucapkan terima kasih kepada pembimbing Dr. Agus Widyantoro dan dewan penguji tesis yang telah memberi masukkan dan saran terhadap tesis saya. Dengan bantuan tersebut artikel hasil penelitian ini dapat diwujudkan.

\section{REFERENCES}

Board of Studies. 1998. English K-6 Modules. New South Wales: Board of Studies.

BSNP. 2006. Standar Isi, Standar Kompetensi Dan Kompetensi Dasar SMP/MTs. Jakarta: Badan Standar Nasional Pendidikan. 
Creswell, J. W. 2008. Educational Research. New Jersey: Pearson Education, Inc.

Gliem, J. A. \& Gliem, R. R. 2003. Calculating, interpreting, and reporting Cronbach's alpha reliability coefficient for Likerttype scales. A paper presented at the Midwest Research-to-Practice Conference in Adult, Continuing, and Community Education, at The Ohio State University, Columbus, $\mathrm{OH}$.

Newby, T. J., et.al.2000. Instructional Technology For Teaching And Learning: Designing Instruction, Integrating Computers And Using Media( $2^{\text {nd }}$ ed.). Upper Saddle River: Prentice-Hall, Inc.

Nurgiyantoro, B. 2001. Penilaian dalam Pengajaran Bahasa dan Sastra. Yogyakarta: BPEE.
Seliger, H. W., \& Shohamy, E. 1989. Second Language Research Methods. Oxford: Oxford University Press.

Thornbury, S. 2002. How to Teach Vocabulary. London: Longman.

Wahana. 2009. Pengolahan Data Statistik dengan SPSS 16.0. Jakarta: Penerbit Salemba Infotek.

Wiersma, W. \& Jurs, S. G. 2009. Research Methods In Education: An Introduction (9th ed.). Boston: Pearson Education.

Zulaiha, R. 2008. Bagaimana Menganalisis Soal Dengan Program ITEMAN. Jakarta: PUSPENDIK. 